$\underline{\text { Research Article }}$

\title{
Microbiological Quality of Table Eggs Sold at Different Sales Location
}

\author{
Fatma YENILMEZ ${ }^{1 *}$ Ayşen BULANCAK ${ }^{2}$
}

\begin{abstract}
In this study, we will compare the microbiological quality of table eggs and aim to shed light on consumer preferences in terms of egg safety. Totally 150 eggs randomly selected and grouped into three groups from 225 eggs which have been purchased 5 different market brands (in cooler cabinet), grocery brand (open) and bazaar (village egg). A total number of Mesophilic Aerobic Bacteria (TMAB), total mold-yeast, Enterobacteriaceae loads and the presence of Salmonella spp. were determined by using commercial kits. According to the research results, market eggs shell had the lowest load in terms of TMAB and mold-yeast $(\mathrm{P} \leq 0.05)$, but higher Enterobacteriaceae load ( $\mathrm{P}>0.05)$. Salmonella spp. determined in one sample from the village and 2 samples from grocery eggs, but none from market eggs. TMAB and total mold-yeast amount were found to be highest in village egg albumens. Market egg albumens and yolk samples were detected free from microorganisms. The results of the analysis show that it would be more safety to prefer market eggs from the cooler cabinets with cold chains. It is necessary to be more careful about village egg consumption because of their microorganism load which can penetrate into eggs by outdoor sale conditions like heat and moisture.
\end{abstract}

Keywords: Consumer preference, egg, microbiological load, sales location

\section{Farklı Satış Noktalarındaki Sofralık Yumurtalarda Mikrobiyolojik Kalite}

\section{Öz}

$\mathrm{Bu}$ araştırmada, market (dolap kullanan), bakkal (açıkta) ve pazarlarda (köy yumurtası) satışa sunulan sofralık yumurtaların mikrobiyolojik kalitesi karşılaştırılarak yumurta güvenliği açısından tüketici tercihlerine 1 şık tutmak amaçlanmıştır. Üç farklı grubun her biri için 5 farklı noktadan satın alınan toplam 225 yumurta içerisinden rastgele seçilen 150 adet yumurtada; Toplam Mezofilik Aerobik Bakteri (TMAB), toplam küfmaya, Enterobacteriaceae yükleri ve Salmonella spp. varlığı araştırılmıştır. Yapılan analizler sonucunda, market yumurtası kabuklarında TMAB ve küf-maya yükünün en düşük $(\mathrm{P} \leq 0.05)$, Enterobacteriaceae yükünün ise en yüksek düzeyde olduğu tespit edilmiştir ( $\mathrm{P}>0.05)$. Salmonella spp. varlığı köy yumurtalarında bir, bakkal yumurtalarında 2 numunede belirlenmiş, market yumurtalarında ise rastlanmamıştır. TMAB ve toplam küf-maya yükü köy yumurtası akında en yüksek düzeyde belirlenirken, market yumurtası ak ve sarı örneklerinde mikroorganizmaya rastlanmamıştır. Analizlerden elde edilen sonuçlar soğuk zincir ve dolap kullanan market yumurtalarını tercih etmenin daha güvenli olacağını göstermektedir. Açıkta satılan yumurtalarda sıcaklık, nem ve olumsuz çevre koşullarından dolayı yumurta içerisine nüfuz edebilecek mikroorganizmalar nedeniyle köy yumurtası tüketiminde daha dikkatli olunması gerekmektedir.

Anahtar Kelimeler: Tüketici tercihi, yumurta, mikrobiyolojik yük, satış yeri

ORCID ID (Yazar sirasına göre)

0000-0001-5470-7974, 0000-0002-4324-9063

\footnotetext{
Yayın Kuruluna Geliş Tarihi: 08.12.2020

Kabul Tarihi: 21.12.2020

${ }^{1}$ Çukurova University, Vocational School of Tufanbeyli, Adana, Turkey

${ }^{2}$ Cyprus International University, Faculty of Agricultural Sciences and Techonologies, Cyprus

*E-mail: fyenilmez@cu.edu.tr, Tel: +90-322-3387784, Fax: +90-322-3387785
} 


\section{Microbiological Quality of Table Eggs Sold at Different Sales Location}

\section{Introduction}

Animal origin foods such as meat and egg products of poultry are concerned as the general reason for a food-borne infection induced by micro-organisms (Sabarinath et al., 2009; Casey et al., 2012). Egg quality can be affected by the contamination of eggs and products with microbes. This can lead to pathogen transmission and consequently spoilage and this causes foodborne infection or consumer poisoning.

Microbial contaminations of eggs commonly take place within few seconds after oviposition, transaction and till consumption (Indhu et al., 2014). Eggs may be infected vertically by; microorganisms from the blood of digestive tract, pass through egg yolk by blood (Gordon and Tucker, 1965) and horizontally depending on the environmental conditions after oviposition by various organisms (Streptococcus and coli-acrogens at artificial insemination) (Harry, 1963), cloacal contact with nest and litter material during oviposition. Other factors may also affect bacterial contamination such as dust in barns and storerooms, shell hygiene or structure (cracks, the existence of cuticle and membrane quality), season and storage conditions (Mallet et al., 2010).

The contamination of the eggshells with microorganisms is mostly through feces. Whenever eggs are laid, they can be contaminated with fecal material and microorganisms may pass through the shell and membranes by vacuum effect which occurred by heat loss of egg after lay. Microorganisms may reach the egg content by unsuitable long storage and transfer conditions (Keller et al., 1995). Contaminated eggs and products may lead to serious health risks when consumed raw or uncooked. The shelf life and food safety of eggs may be adversely affected by high levels of contamination. Nowadays good egg perception of consumers has changed from eggshell hygiene and physical properties into microbial unity by increasing awareness of food safety issues.
Many kinds of bacteria, such as Escherichia, Micrococcus, Salmonella, Streptococcus, Staphylococcus, Aeromonas, Enterobacter, Proteus, Pseudomonas have been determined on the shells of table eggs. Similarly, mold and yeast were also determined (Mayes and Takeballi, 1983; Ricke et al., 2001; Musgrove et al., 2004). On the other hand, the gramnegative Enterobacteriaceae group isolated as a major contaminant of commercial chicken eggs (Arathy et al., 2009; Sabarinath et al., 2009). Salmonella is a gram-negative, selective anaerobic bacteria of the family Enterobacteriaceae. And eggs are one of the most common foods that cause Salmonella infections (Akbaş, 2014).

Storing eggs by cooling is a good method to prevent the growth of pathogens such as Salmonella spp. (EFSA, 2005). Some regulations regarding eggs in different regulations are stated as follows; transport and storage of eggs should be carried out at a constant temperature, providing the best hygiene conditions (EC, 2004-853), eggs must be purchased within 21 days after laying (EC, 2004-853) and the expiry date of eggs must be determined 28 days after laying (EC, 2008589). Turkey is also a candidate country for future membership of the European Union. Turkish government prepared regulations for egg and egg products as Turkish Food Codex Microbiological Criteria (Regulation on Turkish Food Codex Microbiological Criteria, 2011) and Egg Notification (Regulation on Turkish Food Codex Egg Notification, 2014). Turkish regulations asked for storage at $5-8^{\circ} \mathrm{C}$ from the 18th day onwards after the lay of eggs. Enterobacteriaceae load must be lower than $10^{2}$ and free from Salmonella spp.

In light of the above information, this study was conducted to appraise and analyze the impact of different sale locations (market, grocery and bazaar) on microbiological load of table eggs. To investigate TMAB, Mold and Yeast, Enterobacteriace and Salmonella spp. loads of table eggs from the shell, albumen and yolk contents. 


\section{Microbiological Quality of Table Eggs Sold at Different Sales Location}

\section{Material and Methods Sampling}

In this study 225 eggs ( 7 days old, weighing between 63-72 g Large) have been purchased from 5 different market brands (in cooler cabinet), grocery brand (open) and bazaar (village egg). The egg samples were carried to lab immediately and prepared for microbiological analysis. A total of $150 \mathrm{eggs}$ randomly selected and grouped into three (50 eggs for each group): Group1 from the market brand (in cooler cabinet $+4{ }^{\circ} \mathrm{C}$ ), Group2 from grocery brand (open $+24^{\circ} \mathrm{C}$ room temperature) and Group3 from bazaar (village egg, environmental temperature). Eggshells, albumen and yolk were analyzed with commercial kits for TMAB, mold and yeast, Enterobacteriaceae and Salmonella load (log CFU/egg).

\section{Preliminary Preparations for Analysis}

Preparations of Egg Shells: Every 5 eggs were put in a sterile plastic bag, and bags considered as one composite sample. Buffered peptone water $(\mathrm{BPW})$ was $(100 \mathrm{ml})$ poured into the egg samples in sterile bags and stirred, washed and scrubbed with fingers (ISO 6579:1993) for five minutes. Then $225 \mathrm{ml}$ Tryptone Soya Broth (TSB) and $25 \mathrm{ml}$ rinse of BPW mixed well and incubated $18-24$ hours at $37^{\circ} \mathrm{C}$.

Preparations of Egg Albumen and Yolk Content: After sterilization of eggshells with $70 \%$ alcohol; they were broken and separated into contents of yolk and albumen. Each sample from yolk and albumen were pooled in sterile beaker glass to form one sample. Then $225 \mathrm{ml}$ TSB and $25 \mathrm{ml}$ of egg contents mixed for 30 seconds and incubated $18-24$ hours at $37^{\circ} \mathrm{C}$.

\section{Total Mesophilic Aerobic Bacteria (TMAB) Count}

Tenfold dilution was obtained from sterile peptone water up to $10^{-9}$ from homogenized egg contents or eggshells. $1 \mathrm{ml}$ sample with $9 \mathrm{ml}$ TPS inoculated onto PCA (Plate Count Agar) and incubated 24-48 hours at $37{ }^{\circ} \mathrm{C}$. After incubation colonies counted by Most Probable Number (MPN) Method and calculated by logarithmic Colony Forming Unit (log CFU) per egg.

\section{Total Mold-Yeast Count}

For mold-yeast counts, homogenized egg contents or eggshells dilutions used up to $10^{-9}$ with $0.5 \mathrm{ml}$ sterile pipets and spread plate technique on Potato Dextrose Agar (PDA) plates with drigalski spatula. Plates incubated five days at $25^{\circ} \mathrm{C}$ and colonies counted (by MPN Method) and calculated by log CFU per egg.

\section{Enterobacteriacae Count}

Tenfold dilution was obtained from sterile peptone water up to $10^{-4}$ from homogenized egg contents or eggshells. Enterobacteriaceae were enumerated according to Roberts and Greenwood, (1995) with a $1 \mathrm{ml}$ sample onto Violet Red Bile Glucose agar by double plating method (VRBG) (ISO 4832, 2006). Samples were incubated at $30-32^{\circ} \mathrm{C}$ ( 24 hours), colonies counted and calculated by log CFU per egg.

\section{Salmonella spp. Detection}

To start Salmonella spp. detection; the homogenized egg contents and eggshell samples were pre-enriched with peptone water. Then $0.1 \mathrm{ml}$ samples were enriched with Rappaport Vassiliadis and incubated $24 \pm 3$ hours at $41.5 \pm 1{ }^{\circ} \mathrm{C}$. Parallel aliquots $(1 \mathrm{ml})$ from enriched solution added on $10 \mathrm{ml}$ Selenite Cystine Broth Base (SC) and incubated $24 \pm 3$ hours at $37 \pm 1^{\circ} \mathrm{C}$. Each enriched sample plated on Brilliant Green agar (BPLS) and Xylose Lysine Deoxycholate Agar (XLD) at the same time and incubated $24 \pm 3$ hours at $37 \pm 1{ }^{\circ} \mathrm{C}$. Unconfirmed positive colonies were stabbed on both Lysine Iron agar and Triple Sugar Iron agar (TSI) and incubated 24 hours at $37{ }^{\circ} \mathrm{C}$. Positive black tubes with colonies verified with enzyme tests after incubation.

\section{Statistical Analysis}

All data obtained from the experiment were analyzed using the IBM SPSS 19.0 (2010) statistical software package program. The normal distribution of data was analyzed as a completely randomized variance design (ANOVA) and the Tukey test was used for the comparison of means. Statistical significance level was defined as $\mathrm{P} \leq 0.05$. 


\section{Microbiological Quality of Table Eggs Sold at Different Sales Location}

\section{Results and Discussion}

The highest rate of bacterial load detection of table eggs occurred on the eggshell (140/150), followed by albumen $(100 / 150)$ and none at yolk contents $(0 / 150)$ (Table I). There were significant differences $(\mathrm{P} \leq 0.05)$ between shell and albumen detections at the market, grocery and bazaar sale conditions.

Results from the microbial analysis of the Total number of Mesophilic Aerobic Bacteria (TMAB) showed that table eggs collected from grocery and bazaar are more contaminated than eggs from markets. TMAB, mold and yeast,
Enterobacteriaceae were detected in each sale condition of the table eggshells. Bacterial load detection for albumen and yolk contents tested during the study was negative at market sale condition.

The level of TMAB of the surface of the eggshell ranges from $10^{3.8}$ to $10^{7.0} \mathrm{CFU} / \mathrm{egg}$, with an average level around $10^{4.5} \mathrm{CFU} / \mathrm{egg}$ in previous studies (Jones et al., 2004; Musgrove et al., 2005; De Reu et al., 2008; 2009; Nordenskjöld, 2010; Englmaierova et al., 2014; Bulancak et al., 2016; İncili et al., 2019).

Table I. Microbiological load of table eggs from sale conditions (log CFU/egg)

\begin{tabular}{llcccc}
\hline & & $\begin{array}{c}\text { Market } \\
(\mathbf{n = 5 0})\end{array}$ & $\begin{array}{c}\text { Bazaar } \\
(\mathbf{n = 5 0})\end{array}$ & $\begin{array}{c}\text { Grocery } \\
(\mathbf{n}=\mathbf{5 0})\end{array}$ & P Values \\
\hline TMAB & Shell & $8,91^{\mathrm{a}}$ & $10,51^{\mathrm{b}}$ & $11,66^{\mathrm{b}}$ & 0.00 \\
& Albumen & $0,00^{\mathrm{a}}$ & $5,13^{\mathrm{b}}$ & $4,20^{\mathrm{b}}$ & 0.00 \\
& Yolk & 0,00 & 0,00 & 0,00 & - \\
\hline Mold- Yeast & Shell & $6,84^{\mathrm{a}}$ & $9,36^{\mathrm{b}}$ & $8,52^{\mathrm{b}}$ & 0.00 \\
& Albumen & $0,00^{\mathrm{a}}$ & $3,19^{\mathrm{c}}$ & $1,72^{\mathrm{b}}$ & 0.01 \\
& Yolk & 0,00 & 0,00 & 0,00 & - \\
\hline Enterobacteriacea & Shell & 4,15 & 3,43 & 3,03 & 0.80 \\
& Albumen & 0,00 & 0,00 & 0,00 & - \\
& Yolk & 0,00 & 0,00 & 0,00 & - \\
\hline
\end{tabular}

${ }^{\mathrm{a}-\mathrm{c}}$ means followed by different letters in the same row are significantly different.

Significant sample type $\times$ sale condition interaction $(\mathrm{P} \leq 0.05)$

$\mathrm{CFU}=$ colony-forming units

But in this study TMAB load on shell and albumen detected highest as 11.66 and $4.20 \mathrm{log}$ CFU/egg at the grocery; and 10.51 and $5.13 \mathrm{log}$ CFU/egg at bazaar conditions respectively (Table I, $\mathrm{P} \leq 0.05$ ). Our result for the eggshell load of market condition (8.91 log CFU/egg) in agreement with results of Ansah et al., 2009 (7.56 log CFU/egg) and Chaemsanit et al., 2015 (7.2 to $8.00 \log$ CFU/egg). De Reu et al. (2008) stated the limit of $5 \log$ CFU/egg, which can refer to eggshells of acceptable hygienic quality. International Commission on the Microbiological Specification for Food (ICMSF) was identified as acceptable limits of the mean for the eggshell total viable count and mean $\log$ as $10+10^{5}$ and 6.00. And in our study, this count was higher than the specified.
The results show that the current situation is unacceptable according to FAO / WHO egg production standards for all sales conditions.

Mold and yeast load from the shell of bazaar table eggs found the highest amount as $9.36 \mathrm{log}$ CFU/egg. This can be explained by changeable temperature and humidity levels of store conditions of table eggs. The temperature seems to have affected a total load of microorganisms. Mold and yeast load at shell increase by nearly $3 \log$ CFU/egg at the grocery (open $+24{ }^{\circ} \mathrm{C}$ room temperature) and bazaar higher environmental temperatures instead of market (in cooler cabinet $+4^{\circ} \mathrm{C}$ ) condition. Mold and yeast detected at albumen content of eggs as $3.19 \log$ CFU/egg at the bazaar and $1.72 \log$ 


\section{Microbiological Quality of Table Eggs Sold at Different Sales Location}

CFU/egg at grocery sale condition $(\mathrm{P} \leq 0.05)$. Mold and yeast are not detected at market albumens. Karadal et al., (2018) investigate the microbiological quality of the market and village eggs sold at retail in Niğde and Kayseri (Central Anatolian Region of Turkey). Results in this study for eggshell load and albumen content are in agreement with our results $(6.80$ and $6.97 \mathrm{log}$ CFU/egg for market and village eggs respectively, albumen negative at the market condition). Likewise, Ahmed et al., (2002) found mold and yeast load on eggshells $\geq 5 \log$ CFU/egg. Jones et al. (2004) found the lowest yeast and mold levels at 2 weeks of storage $(1.3 \log \mathrm{CFU} / \mathrm{ml})$ at unwashed eggshells. They stored eggs one week more than ours. Microbial populations reached the highest concentration of 2.9 and $2.6 \mathrm{log}$ $\mathrm{CFU} / \mathrm{ml}$ at 8 and 10 weeks, respectively, as storage time increased. Bahobail et al., (2012) study mold and yeast contamination at one week stored eggs found 1.1-3.4 lof CFU/egg. Salem et al. (2009) pointed out that feeds, unhygienic barn and storage conditions may cause the highest level of mold and yeast contamination on shell of table eggs. Likewise, Tomczyk et al. (2019) reported that higher humidity $(95 \%)$ and temperature $\left(20{ }^{\circ} \mathrm{C}\right)$ during the egg storage period may cause the development of fungi in the albumen. In our study mold and yeast load considered to be significantly high because of high temperature and humidity factors.

Enterobacteriaceae loads obtained as 4.15, 3.43 and $3.03 \log$ CFU/eggshell respectively for the market, bazaar and grocery sale conditions (Table I). The difference between the sales conditions was not significant $(P>0.05)$. Albumen and yolk contents are free from Enterobacteriaceae load. İncili et al., (2019) found Enterobacteriaceae load as 1.23 and 1.30 $\log$ CFU/eggshell and 0.71 and $0.70 \mathrm{log}$ CFU/egg for the content of conventional and village eggs, respectively. Their results are in the agreement with our study; that there was no difference between the conventional (market and grocery) and village (bazaar) eggshells in terms of the number of Enterobacteriaceae (P > 0.05). Wall et al. (2008) found a significantly higher proportion of Enterobacteriaceae load in furnished (1-2.3\%) than in conventional cages (5.80\%). Gole et al. (2013) and De Reu et al. (2009) reported 1.46 and $1.51 \log$ CFU/eggshell from furnished cages respectively. Musgrove $e t$ al. (2005) also reported 2.29 log CFU/eggshell from commercial egg processors. In Roberts et al. (2014) study Enterobacteriaceae load was relatively low (1.63 log CFU/egg) in furnished cage eggs and significantly higher (2.10 log CFU/egg) in conventional cage eggs. The change in Enterobacteriaceae loads might be depending on the sampling method. Such as eggs from the cage front directly or from a commercial facility as Musgrove's study (2005). Al-Ashmawy, (2013) reported less contamination for Enterobacteriaceae at white and brown eggshells $(4.9 \times 10,6.3 \times 10 \log 10$ $\mathrm{CFU} / \mathrm{g})$ than home-produced $\left(1.2 \times 10^{2} \log 10\right.$ CFU/g) table eggs from his study. Jones and Musgrove (2007) noticed a higher Enterobacteriaceae load (3.40 log CFU/eggshell) in agreement with our study result.

Enterobacteriaceae levels may be an important criterion in terms of food quality and hygiene of processing conditions (Carter and Cole, 1990). This kind of eggs did not meet the quality standard allowed for this bacteria group as a maximum $10^{2} \log$ CFU/egg for the retail of European Communities (1993), EFSA (2014) and Turkish food safety criteria ISO 21528-2 (2011).

The positive shell emulsion samples for Salmonella spp. were detected in grocery (2/50) and bazaar (1/50) table eggs. Overall there were $2.0 \%(3 / 150)$ positive at eggshell samples. Albumen and yolk contents are free from Salmonella spp. (Table II). Similar findings were reported by Ansah et al. (2009), Chaemsanit et al. (2015) and Stepien (2010) reported a 3.2\% prevalence of Salmonella spp. on eggshells. In this study, Salmonella spp. has not been found internal content of eggs. This finding is in parallel with Stepien-Pysniak (2005) who made a survey about Australian commercial eggs. Gole et al. (2013) found $4.51 \%$ (14/310) Salmonella spp. positive on 


\section{Microbiological Quality of Table Eggs Sold at Different Sales Location}

eggshell and negative at internal content of the egg. İncili et al. (2019) found Salmonella spp. load as $0.69-1.39 \%$ at eggshell and $0-0.69 \%$ for the content of conventional and village eggs, respectively. Their results are in the agreement with our study; that there was no difference between the conventional (market and grocery) and village (bazaar) eggshells in terms of the number of Salmonella spp. (P >0.05).

Table II. Salmonella spp. prevalence of table eggs from sale conditions

\begin{tabular}{llccccc}
\hline & & $\begin{array}{c}\text { Market } \\
(\mathbf{n = 5 0})\end{array}$ & $\begin{array}{c}\text { Bazaar } \\
(\mathbf{n = 5 0})\end{array}$ & $\begin{array}{c}\text { Grocery } \\
(\mathbf{n = 5 0})\end{array}$ & \% & P Values \\
\hline \multirow{3}{*}{ Salmonella spp. } & Shell & $0 / 50$ & $1 / 50$ & $2 / 50$ & 2.00 & 0.05 \\
& Albumen & $0 / 50$ & $0 / 50$ & $0 / 50$ & - & - \\
& Yolk & $0 / 50$ & $0 / 50$ & $0 / 50$ & - & - \\
\hline
\end{tabular}

Results were considered significant when $\mathrm{P} \leq 0.05$.

Adesiyun et al. (2005) recovered Salmonella spp. at layer farms of Trinidad as $3.8 \%$ from eggshell samples and $1.2 \%$ in egg contents (one-day-old egg). They reported that the risk of table egg-induced gastroenteritis is important in Trinidad. They have associated this with, particularly salmonellosis, which occurs as a result of consumption of raw or improperly cooked eggs or egg products. Salmonella spp. was not isolated from farm hen egg contents in Awny et al. (2018) study. While they were isolated from Balady hens' egg content and ducks' eggs content with the incidences of 4 and $8 \%$, respectively. Fikiin et al. (2020) did not detect Salmonella spp. in poultry farms. And they reported that it may be the result of strict spraying and good care practices in poultry farms.

Eggshell surface contamination level and type; may be affected by sanitary conditions of the breeding environment, practices, housing system, geographical area and season. Also, it can occur from one egg to another during egg storage, transport and packaging processes (Techer et al., 2013; Englmaierova et al., 2014). It has been reported that $44-68 \%$ of salmonellosis disorders in the EU are caused by practices during the processing and consumption of eggs and egg products (Hilbert et al., 2014; EFSA, 2015; Fikiin et al., 2020). Eggs should be stored below $7{ }^{\circ} \mathrm{C}$ to control or decrease the microbial load of the eggshell surface (Aygün, 2017). This could also answer the question of why supermarkets had lower amounts of Salmonella spp. than the minimarkets which store the eggs at room temperature. Studies have proven that the rate of changes at unfavorable quality parameters slows down significantly $(\mathrm{P}<0.05)$ by cold storage $\left(8^{\circ} \mathrm{C}\right)$ and lower air humidity conditions (Messens et al., 2005; Nordenskjöld, 2010; Eke et al., 2013; Jones et al., 2018; Tomczyk et al., 2019). Martelli and Davis (2012) were reported that refrigeration decrease SE growth and metabolic activity on the eggshell. Zeidler (2002) was recommended keeping raw eggs at 4- $8{ }^{\circ} \mathrm{C}$ to decrease heat resistance and growth of the Salmonella spp. Pasquali et al. (2016) were reported that a storage temperature of $4{ }^{\circ} \mathrm{C}$ has the strongest inhibiting effect on Salmonella spp., compared with 8 and $20{ }^{\circ} \mathrm{C}$ (Fikiin et al., 2020).

\section{Conclusions}

The results of the analysis show that it would be more safety to prefer market eggs from the cooler cabinet which comes with cold chains. In Turkey egg, consumer groups preferred village eggs between the rates of $83.25-92.8 \%$ as healthy (Mizrak et al., 2012; İskender et al., 2014). The eggs from grocery and village should be therefore taken with caution because of their microorganism load. The public should be warned and educated about the risks of consumption of raw and undercooked egg and egg products. Although the eggs were highly contaminated with total bacteria the absence of 


\section{Microbiological Quality of Table Eggs Sold at Different Sales Location}

Salmonella spp. at the market, eggs are an encouraging factor for consumers. The existing egg handling norms should be revised by introducing transparent and concrete concerns at storage and transport conditions. Food safety and quality characteristics based on temperature and humidity should be determined and applied to a much greater extent.

\section{References}

Adesiyun, A., Offiah, N., Seepersadsingh, N., Rodrigo, S., Lashley, V., Musa1, L., Georges, K. (2005) Microbial health risk posed by table eggs in Trinidad. Epidemiology and Infection, 133(6): 1049-1056. Ahmed, H.F., Deeb, M.M.A., Aman, I.M. (2002) Studies on market hen eggs in Kafr ElSheikh and El-Gharbia Governorates. Vet Med J Giza., 50 (4): 610-615.

Akbaş, E. (2014) Ulusal Mikrobiyoloji Standartları. Volume I: Bulaşıc1 Hastalıklar Laboratuvar Tanı Rehberi; Ankara, Turkey.

AL-Ashmawy, M.A.M. (2013) Prevalence of Enterobacteriaceae in table eggs with particular reference to enterovirulent Escherichia coli strains. International Journal of Poultry Science, 12 (7): 430435.

Ansah, T., Dzoagbe, G.S.K., Teye, G.A., Adday, S., Danquah J.K. (2009) Microbial quality of table eggs sold on selected markets in the Tamale municipality in the Northern Region of Ghana. Livestock Research for Rural Development, 21 (8): 1-12.

Arathy, S., Vanpee, G., Belot, G., Vanessa, M., Claude, D., Ravindra, N.S. (2009) Bacterial contamination of commercial chicken eggs in Canada, West Indies. West Ind. Vet. J., 9 (2): 4-7.

Awny, C., Amer, A.A., Abo El-Makarem, H.S. (2018) Microbial hazards associated with consumption of table eggs. AJVS., 58 (1): 139-146.

Aygün, A. (2017) The eggshell microbial activity. In: Hester, P.Y. (eds), Egg innovations and strategies for improvements. Chapter 13, Academic
Press. pp. 135-144. United States. ISBN: 978-0-12-800879-9

Bahobail, A.A.S, Hassan, S.A., El-Deeb, B.A. (2012) Microbial quality and content aflatoxins of commercially available eggs in Taif, Saudi Arabia. Afr J Microbiol Res., 6 (13): 3337-3342.

Bulancak, A., Baylan, M., Ergınkaya, Z., Toy, N. (2016) Effects of propolis and thyme essential oil as a bio-fumigants on microbiological load of hatching eggs and incubation performance parameters. World's Poultry Science Journal, Volume 72, Supplement I, 5th Mediterranean Poultry Summit, Oral sessions, 20-25 October, Italy-Spain- France, page 41.

Casey, B.B., Ian, T.W., Robert, V.T. (2012) Emerging food borne pathogens and problems; expanding prevention efforts before slaughter or harvest. Improving food safety through one health approach. Work shop summary. National academies press (US), 500 Fifth Street, NW. Washington DC. pp $1-418$.

Carter G.R., Cole R.J. (1990) Diagnostic procedures in veterinary bacteriology and mycology. 5th ed. San Diego, California, USA.

Chaemsanit, S., Akbar, A., and Anal, A.K. (2015) Isolation of total aerobic and pathogenic bacteria from table eggs and its contents. Food and Applied Bioscience Journal, 3 (1): 1-9.

De Reu, K., Messens, W., Heyndrickx, M., Rodenburg, T.B., Uyttendaelle, M., Herman, L. (2008) Bacterial contamination of table eggs and the influence of housing systems. World's Poult.Sci. J., 64: 5-19.

De Reu, K., Rodenburd, T.B., Grijspreerdt, K., Heyndrickx, M., Tuyttens, F.A.M., Sonck, B., Zoons, J., Herman, L. (2009) Bacteriological contamination, dirt, and crack of eggshells in furnished cages and noncage systems for laying hens: an international on-farm comparison. Poultry Science, 88: 2442-2448.

EFSA (European Food Safety Authority) (2005) Opinion of the Scientific Panel on 


\section{Microbiological Quality of Table Eggs Sold at Different Sales Location}

biological hazards (BIOHAZ) related to the Microbiological risks on washing of Table Eggs. EFSA Journal, 269: 1-39.

EFSA (European Food Safety Authority) (2014) European Food Safety Authority, BIOHAZ Panel (EFSA Panel on Biological Hazards). Scientific Opinion on the public health risks of table eggs due to deterioration and development of pathogens. EFSA Journal, 12 (7): 37823929.

EFSA (European Food Safety Authority) (2015) The European Union summary report on trends and sources of Zoonoses, Zoonotic agents and food-borne outbreaks in 2014. EFSA Journal, 13 (12): 4329.

Eke, M.O., Olaitan, N.I., Ochefu, J.H. (2013) Effect of storage conditions on the quality attributes of shell (table) eggs. NIFOJ. 31: 18-24.

Englmaierova, M., Tůmová, E., Charvátová, V., Skřivan, M. (2014) Effects of laying hens housing system on laying performance, egg quality characteristics, and egg microbial contamination. Czech J. Anim. Sci., 59 (8): 345-352.

European Communities (EC) (1993) Microbiological criteria for egg products. The egg products regulations, Available at:

http://www.legislation.gov.uk/uksi/1993/

1520/made (Accessed 24 June 2020).

European Commission (EC) (2004) Regulation No. 853/2004 of the European Parliament and of the Council of 29 April 2004 laying down specific hygiene rules for the hygiene of foodstuffs. Official Journal of the European Union, L 139/55.

European Commission (EC) (2008) Commission Regulation No. 589/2008 of 23 June 2008 laying down detailed rules for implementing Council Regulation (EC) No. 1234/2007 as regards marketing standards for eggs. Official Journal of the European Union, L 163/6.

Fikiin, K., Akterian, S., Stankov, B. (2020) Do raw eggs need to be refrigerated along the food chain? Is the current EU regulation ensuring high-quality shell eggs for the European consumers?, Trends in Food Science \& Technology, 100: 359-362.

Gole, V.C., Chousalkar, K.K., Roberts, J.R. (2013) Survey of Enterobac-teriaceae contamination of table eggs collected from layer flocks in Australia. Int J Food Microbiol. 164 (2-3): 161-165.

Gordon, R.F., Tucker, J.F. (1965) The Epizootiology of Salmonella menston infection of fowls and the effect of feeding poultry food artificially infected with Salmonella. British Poultry Science, 6 (3): 251-264.

Harry, E.G. (1963) The relationship between egg spoilage and the environment of the egg when laid. British Poultry Science, 4 (1): 91-100.

Hilbert F., Paulsen P., Smulders F.J.M. (2014) Safety of food and beverages. In: Motarjemi, Y. (eds), Poultry and eggs. Volume III: Encyclopedia of Food Safety, Academic Press. pp.280-284. San Diego, USA.

IBM Corp. Released (2010) IBM SPSS Statistics for Windows, Version 19.0. IBM Corp. Armonk, NY, USA.

Indhu, B., Muthusami, S., Thirunavukkarasu, N. (2014) Studies on Microflora and their Role on Eggshell Contamination and Infection. Int. J. Pharm. Chem. Bio. Sci., 4 (3): 518-521.

ISO 6579 (1993) Microbiology - General guidance on methods for the detection of Salmonella. International Organization for Standardization, Geneva, Switzerland.

ISO 4832 (2006) Microbiology of food and animal feeding stuffs - Horizontal method for the enumeration of coliforms - Colony-count technique; ISO: Geneva, Switzerland.

ISO 21528-2 (2011) Turkish food safety criteria.

https://www.magenta.com.tr/img/cat/29.1

2.2011-turk-gIda-kodeksi-

mikrobiyolojik-kriterler-yonetmeligiekleri-140.pdf Accessed 27 June 2020.

İncili, G.K., Durmuşoğlu, H., Güngören, A., İlhak, O.I. (2019) Investigation of 


\section{Microbiological Quality of Table Eggs Sold at Different Sales Location}

Microbiological Quality of Conventional (cage type) and Village Eggs Sold in Elazig. The Journal of Faculty of Veterinary Medicine, 12 (2): 97-102.

İskender H., Kanbay Y. (2014) Determination of Egg Consumption Habits University Students. The Journal of The Faculty of Veterinary Medicine University of Yuzuncu Yil, 25 (3): 57-62.

Jones, D.R., Musgrove, M.T., Northcutt, J.K. (2004) Variation in external and internal microbial populations in shell eggs during extended storage. J. Food Prot., 67 (12): 2657-2660.

Jones, D.R., Musgrove M.T. (2007) Pathogen prevalence and microbial levels

Infect Immun, 63 (7): 2443-2449.

Mallet, S., Huneau-Salaun, A., Herman L., De Reu, K. (2010) Laying hen breeding systems and hygienic status of the eggs. Productions Animals, 23: 183-191.

Martelli, F., Davies, R.H. (2012) Salmonella serovars isolated from table eggs: An overview. Food Research International, 45 (2): 745-754.

Mayes, F. J., Takeballi, M.A. (1983) Microbial contamination of the hen's egg: A rewiev. J. Food Prot., 46: 1092-1098.

Messens, W., Grijspeerdt, K., Herman, L. (2005) Eggshell penetration by Salmonella: A rewiev. Worlds Poult Sci J., 61 (1): 71-86.

Mızrak, C., Durmuş, İ., Kamanl1, S., Demirtaş, Ş.E., Kalebaşı, S., Karademir, E., Doğu, M. (2012) Determination egg consumption and consumer habits in Turkey. Turk J Vet Anim Sci., 36 (6): 592-60.

Musgrove, M.T., Jones, D.R., Northcutt, J.K. (2004) Identification of Enterobacteriacae from washed and unwashed commercial shell eggs. J. Food Prot., 67: 2613-2616.

Musgrove, M.T., Jones, D.R., Northcutt, J.K., Cox, N.A., Harrison, M.A. (2005) Shell rinse and shell crush methods for the recovery of aerobic microorganisms and Enterobacteriaceae from shell eggs. associated with restricted shell eggs. $J$ Food Prot., 70 (9): 2004-2007.

Jones, D.R., Ward, G.E., Regmi, P., Karcher, D.M. (2018) Impact of egg handling and conditions during extended storage on egg quality. Poult. Sci., 97: 716-723.

Karadal, F., Onmaz, N.E., Hizlisoy, H., Yıldırım, Y., Al, S., Gönülalan, Z., Ülger, İ. (2018) The Microbiological quality of the village and market eggs sold at retail in Nigde and Kayseri. Journal of Faculty of Veterinary Medicine, 15 (1): 51-57.

Keller, L.H., Benson, C.E., Krotec, K., Eckroade, R.J. (1995) Microorganisms colonization of the reproductive tract of forming and freshly laid eggs of chicken. Journal of Food Protection, 68: 21442148

Musgrove, M.T., Jones, D.R., Northcutt, J.K., Cox, N.A., Harrison, M.A. (2005) Shell rinse and shell crush methods for the recovery of aerobic microorganisms and Enterobacteriaceae from shell eggs. Journal of Food Protection, 68: 21442148.

Nordenskjöld, J. (2010) Study of microflora on egg shells in egg production in Jordan. Independent project/degree project in food science Uppsala Biocenter University of agricultural sciences. EX0426 Independent project/degree project in Food Science. pp.1-30.

Pasquali, F., Klein, G., Reich, F., Manfreda, G., Valero, A. (2016) Modelling survival behaviour of Salmonella enterica ser. Enteritidis, Typhimurium and Tennessee on table eggs during storage at different temperatures. Food Control, 59: 314-319.

Regulation on Turkish Food Codex Microbiological Criteria (2011) 28157. https://www.resmigazete.gov.tr/eskiler/2 011/12/20111229M3-6.htm Accessed 27 June 2020.

Regulation on Turkish Food Codex Egg Notification (2014) 29211. https://www.resmigazete.gov.tr/eskiler/2 014/12/20141220-5.htm Accessed 27 June 2020. 
Ricke, S.C., Birkhold, S.G., Gast, R.K. (2001) products. In: Downes, F.P., Ito, K (eds), Compendium of methods for the microbiological examination of foods, 4th edn. pp. 473-479. Washington, DC.

Roberts, D., Greenwood, M. (1995) Practical food microbiology. Roberts, D (eds), Third Edition, Massachusetts, USA.

Roberts, S.J.R., Chousalkar, K.K. (2014) Effect of production system and flock age on egg quality and total bacterial load in commercial laying hens. Journal of Applied Poultry Research, 23 (1): 59-70.

Sabarinath A., Guillaume V., Guillaume B., Mathew V., DeAllie C., Sharma R.N. (2009) Bacterial contamination of commercial chicken eggs in Grenada. West Indian Veterinary Journal, 9 (2): 47.

Salem, R.M., El-Kaseh R.M., El-Diasty E.M.A. (2009) Study on the fungal contamination and prevalence of Aflatoxins and some antibiotic residues in table eggs. Arab $J$ Biotech., 12 (1): 65-72.

Stepien-Pysniak, D. (2010) Occurrence of Gram-negative bacteria in hens' eggs depending on their source and storage conditions. Polish J Vet Sci., 13(3): 507513.

Techer, C., Baron, F., Jan, S. (2013) Microbial spoilage of eggs and egg products. Egg Meat Symposia. Bergamo, 15-19 September 2013, World's Poultry Science Journal, Volume 69, Supplement. pp.1-6.

Tomczyk, L., Szablewski, T., StuperSzablewska, K.,Nowaczewski, S., Cegielska-Radziejewska, R. (2019) The influence of the conditions of acquisition and storage of table eggs on changes in their quality and the presence of mycobiota and Fusarium mycotoxins. Poultry Science, 98: 2964-2971.

Wall, H., Tauson, R., Sorgjerd, S. (2008) Bacterial contamination of eggshells in furnished and conventional cages. $J$. Appl. Poult. Res. 17 (1): 11-16.

WHO/FAO (2002) Risk assessments of Salmonella in eggs and broiler chickens.
Eggs and egg In Microbiological Risk Assessment Series No.2. Geneva, Switzerland.

Zeidler, G. (2002) Processing and Packaging Shell Eggs. In: Bell D.D. and Weaver W.D (eds), Commercial Chicken Meat and Egg Production. 5th edn. pp. 11291161. New York, USA. 